\title{
MENTAL DETERIORATION IN LAFORA'S DISEASE
}

\author{
A. CUKIERT * - M.M. VILELA * - H.B. SCAPOLAN * \\ B. H. W. LEF'VRE*-L. MARQUES-ASSIS *
}

\begin{abstract}
SUMMARY - Lafora's disease is included among the progressive myoclonic epllepsies. Despite the fact that lementia is a constant finding in this disease only a few papers have studied the timing of niental deterioration. We have performed wide reuropsychological testing in two cases early diagnosed as Lafora disease. The initial neuropsychological testing was carried out by the time there were no complaints of mental deterioration 'n both cases. In the first case consecutive neuropsychological testing demonstrated the rapidly progressive dementia All neuropsychological testings in these cases showed severe impairment of right parietal lobe functions. Higher cortical functions related to language and intelectual processes were best preserved in both cases. The functions related to constructional praxis, memory and abstract concepts and processes were severily impaired. Our data suggest that mental deterioration is an early manifestation in Lafora disease, even by the time normal social life is not yet disturbed. Dominant hemisphere cognitive functions have been less impaired than the non-dominant ones. How a diffuse illness such as Lafora disease can cause such an asymmetrical higher cortical function deficit is not yet clear.
\end{abstract}

\section{Deterioraço mental na doenca de Latora.}

RFSUMO - A doença de Lafora está incluída entre as epilepsias mioclônicas progreşivas. A despelto do fato de que a demência é achado constante nesta doença poucos estudos relatam a marcha de progressão da mesma. Realizamos ampia testagem neuropsicológica em doís casos com diagnóstico precoce de doença de Lafora. A testagem neuropsicológica inicial foi realizada antes do início da deterioracåo mental em ambos os casos. No primeiro caso, testagens neuropsicológicas seriadas demonstraram demência rapijamente progressiva. Todas as testagens destes doentes mostraram acometimento suvero de funçós relacionadas ao lobo parietai direito. Funções corticais superiores relaciolladias a processos intelectuais e linguagem foram melhor preservadas em ambos os casos. As funçöes relacionadas à praxia construtiva, m vóńria e conceitos e processos abstratos foram mals severamente acometidos. Estes dadas sugerem que a deterioração mental é manifestaçăo trecoce da doen§a de Lafora, mesmo em uma etapa em que a vida social e cultural desses pacirntes ainda năo fol afetada. Funções cognitivas relacionadas ao hemisfério dominante foram menos acometidas que aquelas relacionadas a hemisfério nåo dominante. A fisiopatologia do acometimento assimétrico de funçðes corticais superiores nesta doença merece ser melhor estudada.

Lafora's disease is included among the progressive myoclonic epilepsies $\mathbf{2 , 1 8}$. Clinical diagnosis lies upon the finding of generalized seizures that are followed by the appearance of asynchronous arrhythmic and asymmetric myoclonus and a rapidly progressive dementia $3,12,13$. Simple visual partial seizures and/or repeated episodes of visual hallucinations are very frequently seen and are regarded as part of the syndrome by many authors 3,17 . Pathological findings are characteristic and confirm the clinical diagnosis.

Despite the fact that dementia is a constant finding in Lafora's disease, only a few studies have addressed the timing of mental deterioration in these cases, pro-

- Department of Neurology, São Paulo University, School of Medicine. 
bably because the diagnosis was made in patients with an ongoing dementia in most instances. All patients from our out-patients clinic were submitted to routine neuropsychological testing since February 1986. Between 1986 and 1987 two cases of Lafora's disease were early diagnosed using the clinical and pathological criteria described above. Gur routinely neuropsychological testing enable us to gather data from the neuropsychological performance of these two patients before mental deterioration had started.

\section{CASES AND METHODS}

FG (case 1), a 23 year old male was first seen in January 1986 with primarily generalized tcnic-clonic seizures since the age of 18 . Eight years later he developed myoclonus and dementia. He was found twice in a myoclonic status associated with visual hallucinations (one of which was successfully treated with clobazan). Now bedridden and almost unable to talk, he is on 3.0 grams of valproate and $20 \mathrm{mg}$ of clobazan a day. Weekly primarily generalized tonic-clonic seizures still occur. He had his first neuropsychological testing in February 1986, shortly before the onset of a rapldly progressive dementia. At that time, there were no complains of mental deterioration from the patient or his family. Testing was repeated in October 1986 while dementia was evolving. In May 1987 neurospychological testing was impossible.

OPZ (case 2), a 15 year old boy started with episodes that resemble microabsences since the age of ten. At the age of twelve, arrhythmic, asymmetric and asynchronous myoclonus of small amplitude appeared and was followed two years later by primarily generalized tonic-clonic and simple visual partial secondarily generalized seizures. He was tested in February 1987 and by that time no complaints of mental deterioration were recorded and the patient hat had a completely normal social and educational life. The diagnosis of Lafora's disease was made in March 1987 and since then the family has refuzed to further neuropsychological testing.

In both cases, detailed neuropsychological testing comprised items related to the motor functions of the hands, sensation, visual function, oral praxis, ideational praxis, constructional praxis, impressive speech, acoustic-motor organization, memory, intellectual processes and personality. The performances on these tests were rated as nornial, slight deficit, moderate and severe deficits, according to the test used $1,6-8,10,11,16,17,20$ (see resuits). Both patients also had CT scanning and MR imaging studies and repeated EWG tracings. Evoked potentials were obtained from case 1. Liver punction biopsies were evaluated by optic and electron microscopy.

\section{RESULTS}

Pathological examination of liver specimens disclosed typical Lafora's bodies in path cases. Lobular architecture was unchanged. Slight portal fibrosis with occasional short septa were seer. The limiting plate was normal. Many hepatocytes displayed intracytoplasmic eosinophilic bodies with irregular zonal distribution. These bodies were granular, reminiscent of the ground-glass appearance yielded by the surface antigen of the hepatitis virus. In the fixed specimen they are detached from cytoplasmic membranes. Unlike anti-trypsin bodies they do not have a globular appearance and are PAS negative. Electron microscopy in case 1 showed electrolucent spaces Inside the cells which corresponding to the deposit site of the anomalous substances. Cells nuclei and organelles were displaced peripherically near the plasma membrane. Skin biopsy in case 1 obtained from the right arm was normal. CT scans of both cases were normal. Visual and somatosensory evoked potencials were normal in case 1. MRI in case 1 disclosed frontobasal lesions related to a recent severe head trauma. MRI in case 2 was normal. FREG recordings in case 1 disclosed a slow background activity with diffuse polysplke discharge and isolated spike sometimes prevailing in posterior regions during wakefulness. Sleep recordings were very poor in sleep elements and irritative discharges. Intermitent photic stimulation was unable to increase the number of spikes and polyspikes bursts. Case 2 EEG recordings showed a slow background activity with diffuse irregular spike and wave bursts during wakefulness sometimes prevailing in posterior regions. Intermitent photic stimulation slightly increased the number of irritative discharges. Sleep recordings were poor in sleep elements and disclosed rare irritative discharges when compared to the wakefulness recordings.

As can be seen in table 1 , consecutive neuropsychological testing in case 1 demonstrated the evolving mental deterioration. Despite the fact that in the first testing there were no complaints of mental deterioration, neuropsychological testing already disclosed severe deficits. These deficits were more proeminent by the time of the second testing when dementia 


$\begin{array}{ccc}\text { Case 1 } & \text { Case 1 } & \text { Case 2 } \\ \text { First } & \text { Second } & \text { First } \\ \text { testing } & \text { testing } & \text { testing } \\ \text { (Feb-86) } & \text { (Oct-86) } & \text { (Feb-87) }\end{array}$

Motor functions of the hand simple movements 8

kinesthetic Vasis of movement 8

optic spatial crganization 1

dynamic organization 7

$\begin{array}{ccc}\mathbf{N} & \mathbf{N} & \mathbf{N} \\ \mathbf{N} & \mathbf{N} & + \\ \mathbf{N} & \mathbf{N} & \mathbf{N} \\ \mathbf{N} & \mathbf{N} & +++\end{array}$

Sensations

tactile 10

kinesthetic 7

stereognosis 10

$\begin{array}{lll}\mathbf{N} & \mathbf{N} & \mathbf{N} \\ \mathbf{N} & \mathbf{N} & \mathbf{N} \\ \mathbf{N} & \mathbf{N} & \mathbf{N}\end{array}$

Visual functions

figures 16

pictures 16

visual menory 16

intelectual cperations in space 11

Oral praxis 8

Ideational praxis 8

$\begin{array}{ccc}\mathbf{N} & \mathbf{N} & \mathbf{N} \\ \mathbf{N} & +++ & \mathbf{N} \\ + & + & +++ \\ \mathbf{N} & \mathbf{N} & +++\end{array}$

Constructional praxis

\author{
drawing 20 \\ Bender 20 \\ Goldstein Sheerer 6 \\ blocks design (WAIS) 19
}

$\begin{array}{lll}\mathbf{N} & \mathrm{N} & \mathrm{N} \\ \mathrm{N} & \mathrm{N} & \mathrm{N}\end{array}$

Impressive speech

phonemic hearing 8

word comprehension 8

sentences understanding 8

$\begin{array}{ccc}\mathbf{N} & \mathbf{N} & + \\ \mathbf{N} & ++ & + \\ \mathbf{N} & \mathbf{N} & + \\ +++ & +++ & +++\end{array}$

Expressive speech \&

articulation 8

repetitive speech 8

nominative function 8

narrative speech 8

$\begin{array}{lll}\mathbf{N} & \mathbf{N} & \mathbf{N} \\ \mathbf{N} & \mathbf{N} & \mathbf{N} \\ \mathbf{N} & \mathbf{N} & \mathbf{N}\end{array}$

Acoustic-motor organization 7

(rhythmic groups)

$\begin{array}{lll}\mathbf{N} & \mathbf{N} & \mathbf{N} \\ \mathbf{N} & \mathbf{N} & \mathbf{N} \\ \mathbf{N} & \mathbf{H} & \mathbf{N} \\ \mathbf{N} & \mathbf{N} & \mathbf{N}\end{array}$

Memory

visual 8

acoustic 8

digit span (WAIS) 19

$++t+t+\mathrm{N}$

incelectual pr veesses

similarties 19

picture arrangement 19

arithmetic 19

$\begin{array}{ccc}N & N & + \\ + & + & + \\ + & +++ & +++\end{array}$

Personality

$\begin{array}{ccc}\mathbf{N} & \mathbf{N} & + \\ + & + & +++ \\ \mathbf{N} & +++ & +++\end{array}$

anxious $\quad-\quad$ calm 

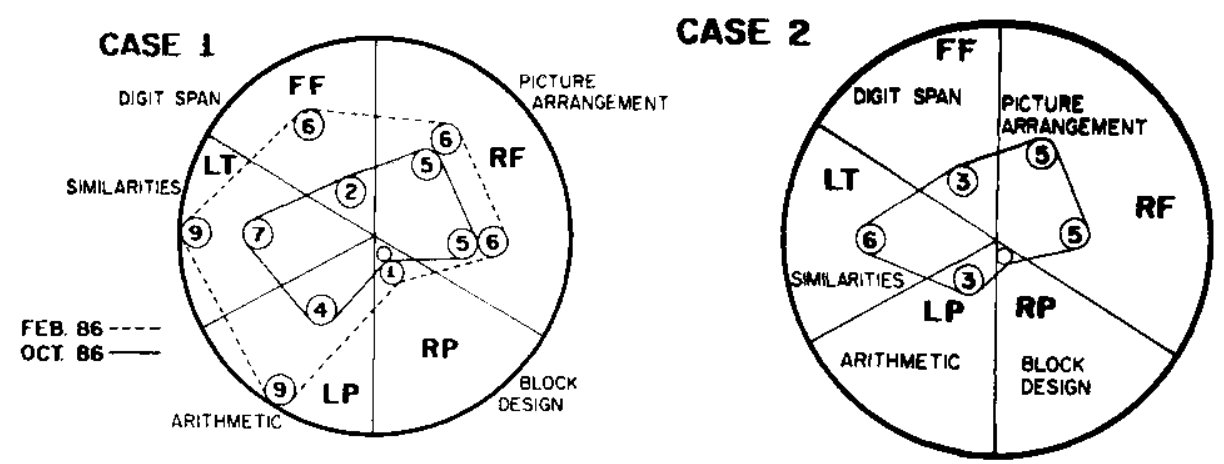

Fig. 1 - McFie's diagram in case 1 and in case 2 . Despite the different stage of the disease, the configuration of the McFie's diagram was very similar, with gross impairment of right parietal functions.

appeared as a symptom. Six months later neuropsychological testing was impossible due to severe cognitivo impairment. As in case 1 , neuropsychological testing in case 2 disclosed severe neuropsychological deficits despite the fact that there were no signs of mental deterioration as informed by his family (a middle class family). The neuropsychological deficits disclosed in case 2 at this stage were as severe as those found in case 1 whlle dementia had already appeared clinically, as can be seen by comparing the McFie's diagram 7 in both cases (Fig. 1). All neuropsychological testings in these cases showed severe inpairment of right parietal functions. Higher cortical functions related to language and intellectual processes were best preserved in both cases. Functions related to constructional praxis, memory and akstract concepts and processes were severily impaired.

\section{COMMENTS}

Lafora's disease in this paper has been diagnosed by means of liver biopsies. Probably representative axilla skin specimens would have led to the same results 4,5.

Simple visual partial seizures and/or episodes of visual hallucinations were present in both cases, being important clues for diagnosis 14. Our data corroborate the idea that mental deterioration is an early manifestation in Lafora's disease even by the time normal social life is not yet disturbed. This contrasts with some reports where mental deterioration has appeared later in the evolution of the disease 15. In general, dominant hemisphere cognitive functions have been less impaired than those related to the non-dominant one. How a diffuse disease such as Lafora disease can cause such an asymmetrical higher cortical function deficit is not clear.

Despite the small number of patients and testings, this paper stresses the importance of the serial neuropsychological testing in the study of an epileptic population. This approach will certainly lead to a better understanding of the progressive dementia in such cases if the number of cases and testings can be increased.

\section{REFERENCES}

1. Berges J, L'Ezine I - The imitation of gestures. Clinics in Developmental Medicine 18. William Fieinemann, London, 1965.

2. Berkovic SF, Andermann F, Carpenter S, Wolfe LS - Progressive myoclonus epilepsy: spectfic causes and diagnosis. N Engl J Med 315:296, 1986.

3. Boudouresques J, Roger J, Khalil R, Pelissier JF, Cherif AA, Tafani B, Champlon MF - Deux cas flamiliaux de maladie de Lafora. Rev Neurol (Parls) 34:523, 1978.

4. Busard HLSM, Gabreels-Festen AAWN, Renier WO, Gabreels FJM, Stadhouders AM Axilla skin biopsy: a reliable test for the diagnosis of Lafora disease. Ann Neurol $21: 599,1987$. 
5. Carpenter $S$, Karpati $G-$ Sweet gland duct cells in Lafora disease: diagnosis by skin blopsy. Neurology 31:1564, 1981.

6. Goldstein Y.. Scheerer $\mathbf{M}$ - Abstract and Concrete Behaviour: an Experimental Study with Specia! Tests. Psychological Monographs. American Psychological Association, Washington, 1941.

7. Lefèvre A - Exame Neurológicon Evolutivo. Sarvler, Såo P\&ulo, 1972.

8. Luria AR - Higher Cortical Functions in Man. Basic Books, New York, 1966.

9. McFie $J$-- The diagnosis of disonders of higher cortical activity: syndromes related to frontal, temporal, parietal and occipital lesions. In Vinken PJ, Bruyn GW: Handbook Clinical Neurolngy, Vol 4. North Holland, Amsterdam, 1959.

10. Plaget J, Irhelder B - La Representation de l'Espace Chez l'Enfant. Presses Universitalres de France, Paris, 1948.

11. Raven JC - Coloured Progressive Matrices. Lewis, London, 1956.

12 Roger J, Castaut H, Toga M, Soulayrol R, Regis H, LoD H, Tassinari A, Dubois A, Poinso $\mathrm{Y}$, Mesdjian E - Epllepsie mioclonique progressive avec corps de Lafora: étude clinique, foligraphique et anatomique d'un cas. Rev Neurol (Paris) 112:50, 1965.

13. Roger J, Gistaut H, Boudouresques J, Toga M, Dubols D, Lob H - Epilepsie myoclonique progressive avec corps de Lafora: étude clinique et poligrarhique; controle anatomique ultrastructural. Rev Neurol (Paris) 116:197, 1967.

14 Roger J, Yelisgier JF, Bureau M, Dravet C, Revol M, Tinuper P - Le diagnostic précoce de la maladie de Lafora: importance des manifestations visuelles et interêt de la biopsie cutanée. Fev Neurol (Parłs) 139:115, 1983.

15. Tassinari CA, Bureau-Paillas M, Dalla-Bernardina B, Picomell-Darder I, Mouren MC, Dravet C, Foger J - La maladie de Lafora. Rev EEG Neurophyslol 8:107, 1978.

16. Terman LM, Merril MA - Stanford-Binnet Intelligence Scale. Houghton Mifflin, Boston, 1960.

17. Tinuper P, Aguglia U. Pelissier JF, Gastaut $H-$ Visual irtal phenomena ir, a case of Lafora disease proven by skin biopsy. Epilepsis 24:214, 1983.

18. Van-Heycop-ten-Ham M, De Jager H - Progressive myoclonus epilepsy with Lafora bodies: clinical-pathological features. Epilepsia 4:95, 1963.

19. Wechsler $\mathbf{D}-$ The Measurement and Appraisal of Adult Intelligence. Williams \& Wilkins, Baltimore, 1958.

20 Zazzo R - Manual para o Exame Psicológico da Criança. Mestre Jou, São I’aulo, 1968. 